\title{
The Implementation of Inquiry Based Learning toward Students' Learning Outcomes and Critical Thinking Skills
}

\author{
Muhammad Zaini, Kaspul, M. Arsyad \\ Biology Education Study Program \\ Universitas Lambung Mangkurat, \\ Banjarmasin, Indonesia \\ muhammadzaini@unlam.ac.id
}

\begin{abstract}
This research aimed to (1) test the effect of inquiry based learning toward learning outcome of cognitive product and cognitive process, (2) test the effect of inquiry-based learning toward critical thinking skills. Implementation this model using the quasi-experimental. The independent variable was inquirybased learning while the dependent variables were learning outcome of cognitive product, cognitive process, and critical thinking skills. This research population was grade 11th students from SMA Negeri 1 Sungai Tabuk i.e. XI IPA-1, XI IPA-2, and XI IPA-3. This research samples for implementation of inquirybased learning toward learning outcomes for the first treatment classes were XI IPA-2 and XI IPA-3, while the control class was XI IPA-1. The second treatment classes were XI IPA-1 and XI IPA-2, while the control class was XI IPA-3. The treatment classes were determined by using purposive sampling technique. This research samples for implementation of inquiry based learning toward critical thinking skills were XI IPA-2 and XI IPA-3, while the control class was XI IPA-1. This research was held for 3 months. The instrument to measure the cognitive product and cognitive process consisted of multiple-choice test and the critical thinking skills consisted of essay test. The data were analyzed by using anacova SAS release 9.1.3. The results are (1) inquiry base learning has effect to learning outcome of cognitive product and cognitive process, (2) inquiry base learning has no effect to the ability to apply, but has effect to the ability to analyze and the ability to evaluate.
\end{abstract}

Keywords-Critical Thinking Skills, Inquiry Model, Learning Outcome

\section{INTRODUCTION}

One of the problems in facing educational world in Indonesia is that there is weakness of learning process. In the learning process, students are less encouraged to develop the ability to think. Learning in the classroom is only directed to memorize information without being required to understand what they have memorized [1][2]. The survey results of Trends in International Mathematics and Science Study (TIMSS) in 2011 reported that the percentage of Indonesian students ranked in 40th out of 42 countries. Indonesian students placed in 31 st rank of the mid-level reasoning, in 41st rank of low-level reasoning and in 38th rank of the mid-level of ability to know [3]. These results are consistent to the report of Program for International Student Assessment (PISA) in 2012 in which the ranking of students' critical thinking skills is 64 th from 65 countries [4].

Ref [5] released a report of PISA from 2000-2009 and showed that overall Indonesian students' science literacy is in the range of $30-40 \%$. Based on the results of this study, the learning process and assessment need to be designed to stimulate the increase of scientific literacy. Designing inquirybased learning and innovation is an alternative to deal with this issue.

Inquiry-based learning has been often implemented. The use of this model has improved students' learning outcomes $[6][7][8][9][10][11][12][13][14]$. The use of this model has also increased the ability to think [9]. It is effective in demanding students to develop and evaluate their own hypotheses and obtain their own conclusions [15]. Critical thinking skills are obtained through inquiry and observation.

Learning is a relatively permanent change in behavior through experience and training [16]. Learning is successful if there are distinct behavior changes in students. The science learning through inquiry involves science process and skills used by scientists to study and assist students in applying the skills [17].

The learning outcomes are widely interpreted in a model to include not only the cognitive and grade point, but also a wide range of behaviors and attitudes [18]. The learning process inside and outside school produces three capabilities known as a bloom taxonomy consisting of cognitive abilities, affective and psychomotor [19].

Critical thinking is represented by the skills of critical thinking: (1) inference, (2) the introduction of assumptions, (3) deduction skills to determine conclusions, (4) interpretation, and (5) evaluation [20]. Interpretation is the ability to understand and express the meaning of the various experiences, circumstances, data, events, consideration, conventions, beliefs, rules, procedures or criteria [21]. Inference is like concluding an image of some of the presented 
supporting data. Explaining/describing is the ability to express and justify the reasoning in relation to the conceptual, methodological, criteria and considerations based on the underlying context.

The increase of critical thinking skills through; (1) reading, (2) listening, (3) observing, and (4) analyzing [22]. Based on the aforementioned proposals, the research question was formulated as follow: Does the inquiry-based learning in biology learning affect the learning outcomes and high school students' critical thinking skills?.

\section{METHOD}

The design of this study was distinguished into two types. Types 1 was the implementation of inquiry-based learning model on learning outcomes using a quasi-experimental with counter balance design, as shown in Figure 1.

\begin{tabular}{|cr|}
\hline O1 & Oo \\
\hline Oo & O2 \\
\hline
\end{tabular}

Fig 1. The Model Design of Counter Balance Study

Where are O1: Treatment Class I (The Concept of Circulatory System); Oo: Class Control; and O2: Treatment Class II (The Concept of Motion Systems)

Types 2 was the implementation of inquiry-based learning model in the ability to think also uses quasi-experimental with the design of the nonequivalent control group design, as shown in Figure 2.

\begin{tabular}{|ccc|}
\hline O1 & X & O2 \\
-------------- \\
O1 & & O2 \\
\hline
\end{tabular}

Fig 2. The Model Design of the Nonequivalent Control Group Design

Where are O1: Pretest; O2: Posttest; and X: Treatment

The independent variable was inquiry-based learning. The dependent variable was the learning outcomes of cognitive product, the learning outcomes of cognitive process, and critical thinking skills. Control variable was the number of lesson hours, syllabus, educational background of teachers and teaching materials.

The research population of XI class students of SMAN 1 Sungai Tabuk Banjar consisted of three classes, namely XI-1 XI-2 and XI-3 class. The following is the division of the research sample: (1). To examine the significance of the implementation of inquiry-based learning model on learning outcomes, the treatment classes I were XI-2 and XI-3 classes, while the control class was XI-1 class. The treatment classes II were XI-1 and XI-2 classes, while the control class was XI
IPA-3 class. The treatment classes were determined by using purposive sampling technique; (2) To examine the significance of the implementation of inquiry-based learning model on critical thinking skills, the treatment classes were XI-2 and XI-3 classes, while the control class was XI-1 class.

The research was conducted in three months (OctoberDecember 2016) in SMA Negeri 1 Sungai Tabuk Jl. Gerilya Sungai Tabuk Kramat, District Banjar.

The research instruments used in this research were (1) an instrument to measure cognitive product which consisted of a multiple choice test; (2) an instrument to measure cognitive process which consisted of a multiple choice test, and; (3) an instrument to measure critical thinking skills which consisted of an essay test.

A multiple-choice test and an essay test were validated using Rasch models [23]. The data collection and analysis techniques were distinguished into: (1) the learning outcomes of cognitive product were obtained through a multiple choice test, which was given a score of 1 if it is correct and 0 if it is wrong; (2) The learning outcomes of cognitive process is obtained through a multiple-choice test, given a score of 1 if it is correct and 0 if it is wrong; (3) the results of learning critical thinking skills is obtained through an essay test, scored using a rubric essay test. Each data group was compared with the control group, using the anacova program of SAS 9.1.3. version.

\section{RESULTS}

\section{A. Learning Outcomes}

The results of the cognitive learning products and cognitive processes processed using anacova are presented in Table 1. Table I shows the average difference of the learning outcomes of cognitive product between treatment class and control.

TABLE I. SUMMARY OF THE LEARNING OUTCOMES OF COGNITIVE PRODUCTS AND COGNITIVE PROCESSES

\begin{tabular}{|l|c|c|c|c|c|}
\hline \multirow{2}{*}{$\begin{array}{c}\text { Biology } \\
\text { Concept }\end{array}$} & \multirow{2}{*}{$\begin{array}{c}\text { Learning } \\
\text { Outcomes }\end{array}$} & \multicolumn{2}{c|}{ Control Class } & \multicolumn{2}{c|}{ Treatment Class } \\
\cline { 3 - 6 } Curculatory & $\begin{array}{c}\text { Cognitive } \\
\text { System }\end{array}$ & 41.94 & 60.54 & 50.61 & 70.18 \\
\cline { 2 - 6 } & Product & 40.54 & 56.88 & 49.09 & 63.15 \\
\hline $\begin{array}{l}\text { Movemement } \\
\text { System }\end{array}$ & $\begin{array}{c}\text { Cognitive } \\
\text { Product }\end{array}$ & 35.00 & 60.00 & 36.00 & 65.00 \\
\cline { 2 - 6 } & Cognitive Process & 41.00 & 44.00 & 42.00 & 73.00 \\
\hline
\end{tabular}

Table II. shows the average difference of the learning outcomes of cognitive product between treatment class and control class. The same thing applies to the learning outcomes of cognitive process. The significance test of the average difference using anacova is summarized in Table 2. 
TABLE II. SUMMARY OF COVARIANCE ANALYSIS OF STUDENT OUTCOMES

\begin{tabular}{|l|c|c|c|c|c|c|c|}
\hline $\begin{array}{c}\text { Biology } \\
\text { Concept }\end{array}$ & $\begin{array}{c}\text { Learning } \\
\text { Outcome } \\
\mathbf{S}\end{array}$ & $\mathbf{N}$ & $\begin{array}{c}\mathbf{F}- \\
\text { ratio }\end{array}$ & $\mathbf{P r}>\mathbf{F}$ & $\mathbf{R}^{\mathbf{2}}$ & $\mathbf{c . v .}$ & $\begin{array}{c}\text { Descri } \\
\text { ption }\end{array}$ \\
\hline \multirow{2}{*}{$\begin{array}{c}\text { Circulatory } \\
\text { System }\end{array}$} & $\begin{array}{c}\text { Cognitive } \\
\text { Product }\end{array}$ & 85 & 42.95 & $<.0 .001$ & 0.50 & 9.64 & $\begin{array}{c}\text { Signifi } \\
\text { cant }\end{array}$ \\
\cline { 2 - 8 } & $\begin{array}{c}\text { Cognitive } \\
\text { Process }\end{array}$ & 85 & 94.84 & $<.0 .001$ & 0.69 & 7.83 & $\begin{array}{c}\text { Signifi } \\
\text { cant }\end{array}$ \\
\hline \multirow{2}{*}{$\begin{array}{c}\text { Movement } \\
\text { System }\end{array}$} & $\begin{array}{c}\text { Cognitive } \\
\text { Product }\end{array}$ & 85 & 37.84 & $<0.001$ & 0.47 & 3.29 & $\begin{array}{c}\text { Signifi } \\
\text { cant }\end{array}$ \\
\cline { 2 - 8 } & $\begin{array}{c}\text { Cognitive } \\
\text { Process }\end{array}$ & 85 & 54.56 & $<0.001$ & 0.56 & 8.92 & $\begin{array}{c}\text { Signifi } \\
\text { cant }\end{array}$ \\
\hline
\end{tabular}

Table 2. shows that there is an effect of inquiry-based learning in biology learning to the cognitive products learning outcomes $(\mathrm{F}$-ratio $=42.95 ; P=0.001$ and $\mathrm{F}$-ratio is $37.84, P=$ $0.001)$. There is an effect of inquiry-based learning in biology learning to the cognitive processes learning outcomes (F-ratio $=94.84 ; P=0.001$ and $\mathrm{F}$-ratio is $54.56, P=0.001)$.

\section{B. Critical Thinking Skill}

Learning outcomes of the effect of inquiry-based biology learning to high school students' critical thinking skills is summarized in Table III.

TABLE III. SUMMARY OF COVARIANCE ANALYSIS ON VARIOUS PARAMETER OF STUDENTS' CRITICAL THINKING SKILLS

\begin{tabular}{|l|c|c|c|c|c|c|c|}
\hline Indicator & Parameter & $\mathbf{N}$ & $\begin{array}{c}\mathbf{F}- \\
\text { ratio }\end{array}$ & $\mathbf{P r}>\mathbf{F}$ & $\mathbf{R}^{2}$ & $\mathbf{c . v}$. & $\begin{array}{c}\text { Descri } \\
\text { ption }\end{array}$ \\
\hline Application & Determine & 60 & 1.03 & 0.360 & 0.03 & 5.29 & $\begin{array}{c}\text { No } \\
\text { Signific } \\
\text { ant }\end{array}$ \\
\hline Analysis & $\begin{array}{c}\text { Giving } \\
\text { Attribute }\end{array}$ & 62 & 39.75 & 0.001 & 0.57 & 35.13 & $\begin{array}{c}\text { Signific } \\
\text { ant }\end{array}$ \\
\hline Analysis & Integration & 61 & 2.83 & 0.050 & 0.08 & 29.24 & $\begin{array}{c}\text { Signific } \\
\text { ant }\end{array}$ \\
\hline Analysis & Analysis & 61 & 11.89 & 0.001 & 0.29 & 13.10 & $\begin{array}{c}\text { Signific } \\
\text { ant }\end{array}$ \\
\hline Evaluation & Improving & 61 & 2.70 & 0.050 & 0.08 & 46.00 & $\begin{array}{c}\text { Signific } \\
\text { ant }\end{array}$ \\
\hline
\end{tabular}

Table 3 shows that there is no significant effect of inquirybased learning biology to the ability to apply (F-ratio $=1.03 ; P$ $=0.36)$. There are significant differences in ability to analyze $($ F-ratio $=39.75 ; P=0.001 ;$ F-ratio $2,83,56 ; P=0.05 ;$ F-ratio is $11.89, P=0.001)$. There are significant differences in the ability to evaluate $($ F-ratio $=2.70 ; P=0.05)$.

\section{DISCUSSION}

\section{A. The Effect of Inquiry Based Learning on the Learning Outcomes of Cognitive Products}

Inquiry-based learning can improve the learning outcomes of cognitive product and has significant effect. This finding is consistent with the research that has been reported previously by [24] although a lot of research explains that inquiry-based learning affects the learning outcomes [7][8][11][12][13][14]. The researchers above did not distinguish between the learning outcomes of cognitive product and cognitive process, as set out in the Ministerial Regulation number 41 of 2007 [25].

Separating the learning outcomes between cognitive product and cognitive process is not without reason because learning is a process. It is an activity and not a result or goal [26]. Learning is a process of change in behavior, from not knowing into knowing [27].

Ironically, the learning outcomes are not measurable because the words used to formulate the learning outcome are not operational, as reported in other studies [28], [9]. They use the term "understanding" as the embodiment of learning outcomes.

\section{B. The Effect of Inquiry Based Learning on the Learning Outcomes of Cognitive Process}

Inquiry-based learning can improve learning outcomes of cognitive processes and has significant effect. These findings are supported by previous studies [24], [29]. Other studies have generally explained that the inquiry-based learning affects the learning outcomes. For example it only affects the learning outcomes [12], or using the word construct such as the "understanding" of learning outcomes [7], [8], [9], [11], [14], [28].

The use of construct word in formulating research objectives has obscured the research objectives to be achieved. In fact, it should to be measured because it reflects the process of change in behavior [27]. In general, the results of the research do not distinguish between cognitive products and cognitive process [6], [8], [9].

Inquiry-based learning is significant to the learning outcomes of cognitive process because there are tasks to be accomplished together, so there should be a division of work. The effective communication will facilitate cooperation within the group. Thus, the opportunity to understand the learning material will be better. More importantly, the education is directed to the process of finding a concept, not just memorizing concept.

\section{The Effect of Inquiry-Based Learning on the Critical Thinking Skills}

Inquiry-based learning does not affect the ability to apply, but it affects to the ability to analyze and evaluate. This research divides the indicator of the ability to think critically, in contrast to some studies that have been reported previously, without outlining the indicator of critical thinking skills [9], [11][30].

One of the studies has found the indicator of critical thinking skills which is the ability to explain [14]. Nevertheless, the ability to explain according to Bloom's Taxonomy does not include the critical thinking skills [31].

Many studies have only measured the critical thinking skills [24][29][32][33][34] although there are undifferentiated indicators to be achieved [24][34]. However, the research which carried out in groups does not reflect individual skills. 
Inquiry-based learning in biology learning does not affect the ability to apply. This can be understood because the ability to apply (C3) does not require a high ability to achieve it. As a comparison of skills to formulate the problem and formulate hypotheses through descriptive research can be equated with the ability to apply which is also obtained by a good category [35]. Therefore, it uses the benchmark for critical thinking skills which is a prerequisite to acquire critical thinking skills.

Inquiry based-learning has effect toward the ability to analyze and ability to evaluate. This is contrasted with the previous research by [35] in which the ability to analyze and ability to make conclusions show any improvements. Otherwise, Ref [24] found that ability to formulate the problems, formulate hypotheses, collect and analyze the data, and make conclusions are classified as good.

\section{CONCLUSION}

Based on the research and discussion, it is concluded that inquiry-based learning on biology learning has effect to learning outcome of cognitive product. Inquiry-based learning on biology learning has effect to learning outcome of cognitive. Morever, inquiry-based learning on biology learning has no effect to the ability to apply, but has effect to the ability to analyze and the ability to evaluate.

\section{REFERENCES}

[1] W. Sanjaya, Learning Strategy That Oriented With Educational Process Standard, Jakarta: Kencana, 2007.

[2] S. Warandi, A. T. Widodo and N. E. Priyani, "Improvement of students' learning outcome through science process skills approach oriented with problem based instruction," Chemistry Education Innovation Journal, vol. 3, no. 1, 2009.

[3] M. O. Martin, I. V. Mullis, P. Foy and G. M. Stanco, "TIMSS 2011 International Results in Science," International Association For The Evaluation of Educational Achievement, Herengracht 487, Amsterdam, 1017 BT, The Netherlands, 2012.

[4] PISA, "PISA 2012 Results: What Students Know and Can Do: Student Performance in Mathematics, Reading and Science," PISA, 2014.

[5] Wasis, "Science Learning And Assessment That Suitable To Curriculum 2013's Demand," in National Seminar 2015 Surabaya, January 24th 2015. Science Education Study Program, Graduate Program, Universitas Negeri Surabaya, Surabaya, 2015.

[6] T. Khairunnisa, "Students' Learning Outcome and Critical Thinking Ability of Grade X SMA Negri 1 Sungai Tabuk on Waste Types and Waste Recycle Concept Using Inquiry Learning Model," Undergraduate Thesis. Biology Education Study Program FKIP Unlam, Banjarmasin, 2010

[7] I. Rosmalina, "Implemetation of Inquiry-Based Instructional Materials on Concept Codepedency in Elementary Schools at Sub-distric Beruntung Baru District Banjar," Undergraduate Thesis, Biology Education Study Program FKIP Unlam, Banjarmasin, 2010.

[8] R. Ariyani, "Improving Grade IX Students' Comprehension of SMP Negeri 9 Banjarmasin on Biotechnology Concept Through Inquiry Approach," Undergraduate Thesis. Biology Education Study Program FKIP Unlam, Banjarmasin, 2011.

[9] Y. W. Wati, "Contextual Learning Application With Inquiry Approach on Fungi Concept to Improvee Students' Thinking Abilityvand Students' Learning Outcome on Grade X SMAN 2 Banjarmasin," Undergraduate Thesis. Biology Education Study Program FKIP Unlam, Banjarmasin, 2012.

[10] S. Schaal, S. Grubmeyer and M. Matt, "Outdoors and online-inquiry with mobile devices in pre-service science teacher education," World Journal On Education Technology, vol. 4, no. 2, pp. 113-125, 2012.

[11] N. W. Anggareni, N. P. Ristiadi and N. L. Widiyanti, "Implemetation the strategy of inquiry based-learning toward junior high school students' critical thinking ability and concept comprehension," Science Education Journal, vol. 3, no. 1, 2013.

[12] N. L. Dewi, N. Andres and I. W. Sadia, "The effect of guided inquiry learning model toward scientific manners and science learning outcomes," e-Journal Graduate Program of Ganesha University of Education, vol. 3, 2013.

[13] A. N. Rohmawati, "The Application of Integrated Science Learning With Inquiry Model on Eyes theme at SMPN 1 Maduran lamongan," Universitas Negeri Surabaya, Surabaya, 2013.

[14] A. Suwondo, E. S. Mujiwati and M. Nurmilawati, "The Effect of Inquiry Learning Model Supported With Real Media Toward The Ability to Explain Relationship Between Plant's Root Structures With Function On Students Grade IV of SDN Burengan 2 Kediri," Universitas Negeri Surabaya, Surabaya, 2015.

[15] S. Lohner, W. R. Van Joolingen, E. R. Savelsbergh and B. Van-HoutWolters, "Student's reasoning during modeling in an inquiry learning environment," Computer in Human Behavior, vol. 21, no. 3, pp. 441461, 2005.

[16] H. Cahyono and S. Haryanto, "Increasing motivation and science learning achievement through the implementation of outdoor cooperative learning model in class VIII SMN 2 Banguntapan academic year 2015/2016," Journal of Education and Practice, vol. 7, no. 26, pp. 21-26, 2016.

[17] J. W. McBride, M. I. Bhatti, M. A. Hannan and M. Feinberg, "using an inquiry approach to teach science to secondary school science teachers," Physics Education, vol. 39, no. 5, p. 434, 2004.

[18] T. R. Guskey, "Professional development and teacher change," Teachers and Teaching, vol. 8, no. 3, pp. 381-391, 2002

[19] T. L. Ferris and S. Aziz, "A Psychomotor Skills Extension to Bloom's Taxonomy of Education Objectives For Engineering Education," Doctoral Dissertation, National ChengKung University, Taiwan, 2005.

[20] A. Fisher, Critical thinking: A Introduction, UK: Cambridge University Press, 2011..

[21] P. A. Facione, Critical Thinking: What It Is and Why It Counts, Milbrae, CA: The California Academiv Press, 1998S.

[22] D. Schafersman, "An introduction to critical thinking," Retrieved March, vol. 5, p. 2008, 1991.

[23] B. Sumintono and W. Widhiarso, The Application of Rasch Model on Education Assessment, Cimahi: Komunikata Team, 2015.

[24] M. Zaini, "Guided inquiry based learning on the concept of ecosystem toward learning outcomes and critical thinking skills of high school students," IOSR Journal Of Research \& Method in Education (IOSRJRME), vol. 6, no. 6, pp. 50-55, 2016.

[25] BSNP, "Regulation of Indonesian Minister of Education Number 41 Year 2007 About Process Standar," BSNP, Jakarta, 2007.

[26] Husamah, Learn and Learning, Malang: UMM Press, 2016.

[27] E.Mulyatiningsih, Methods of Application Research in Education, Yogyakarta: Alfabeta Publisher, 2013.

[28] O. Belawati, "The Usage of Inquiry Approach Toward Survival Organisms Concept Comprehension in SMPN 1 Anjir Muara Batola," Undergraduate Thesis. Biology education Study Program FKIP Unlam, Banjarmasin, 2009.

[29] M. Zaini and D. J. Asnida , "The Development of Science-Biology Learning Instrument Oriented to Mangrove Forest For Junior High School Student," in Proceeding in Biology Seminar, Banjarmasin, 2016.

[30] M. Zaini and R. Rusmini, "Learning Set Development on Objects Classication Concept Toward Junior High School Students's Critical Thinking Ability," in Proceeding in Biology Seminar, Banjarmasin, 2016

[31] A. N. Bissel and P. P. Lemons, "A New method for assessing critical thinking in the classroom," Bioscience, vol. 56, no. 1, pp. 66-72, 2006. 
[32] Raihanah, "The Effect of Guided-Inquiry Learning Model Application Toward Students' Learning Outcome at Grade X SMA Negeri 4 Banjarmasin on Sub-Concept of Ecosystem Components," Undergraduate Thesis. Biology Education Study Program FKIP Unlam, Banjarmasin, 2015.

[33] D. Harmawati, I. Sri Endah and A. Gofur, Improving The Character and Critical Thinking Through Inquiry-Based Learning, Malang: UMM, 2016.

[34] Norhasanah, "Improving Students' Process Skill on Class X5 SMAN 4 Barabai Through The application of Guided-Inquiry Model on Ecosystem Concept," UMM, Malang, 2016.

[35] N. Hidayati, "Learning Outcome and Critical Thinking Ability of Madrasah Tsanawiyah Students in Science Learning Through Scientific Work," in The 13th National Seminar UNS, Solo, 2016. 